\title{
New types of washers and foundation bolts for seating marine diesel engines
}

\author{
New types of polymer-metal washers and foundation bolts fitted in polymer have been presented, applied for seating \\ diesel engines in marine engine rooms. Test results have been given for the washers'compression and shear strength in \\ the polymer-metal separation surfaces.
}

Key words: marine engines, polimers, engine seating

\section{Nowe typy podkładek i śrub fundamentowych dla posadowienia okrętowych silników spalinowych}

\author{
W artykule przedstawiono nowe typy podktadek polimerowo-metalowych i śrub fundamentowych pasowanych w poli- \\ merze, stosowanych do posadowienia silników spalinowych $w$ siłowniach okrętów. Podano wyniki badań wytrzymałości \\ podktadek na ściskanie i ścinanie w powierzchniach rozdzialu polimer-metal. \\ Slowa kluczowe: silniki okrętowe, polimery, posadowienie silnika
}

\section{Introduction}

According to the patent [1], the method of seating diesel engines on foundations (Fig. 1) consists in inserting metal separators in the clearances between engine feet and foundation shelves.

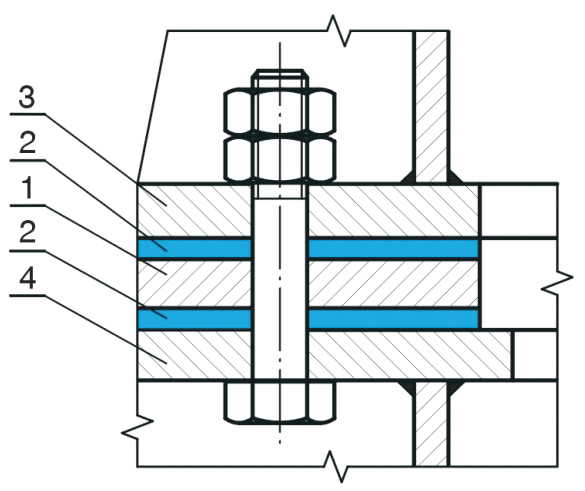

Fig. 1. Diagram of polymer-metal washer for seating a diesel engine on the foundation [1]: 1- metal separator, 2 - polymer composite, 3 - engine foot, 4 - foundation shelf, 5 - foundation bolt

Rys. 1. Schemat podkładki polimerowo-metalowej dla posadowienia silnika spalinowego na fundamencie [1]: 1 - przekładka metalowa, 2 - kompozycja polimerów, 3 - stopa silnika, 4-pótka fundamentu, 5 -śruba fundamentowa

Compared to the traditional casting of washers from polymer composites, the method of seating the diesel engine on the foundation according to the invention [2] eliminates the construction of forms and washer inlet systems, which reduces labour and polymer composite consumption, limits washer creep, decreasing the relaxation of foundation bolts' tension, enabling the application of metal separators of equal thickness on the engine total length, at the same time preserving the chief merits of metal washers, eliminating their strenuous fitting to the engine foot surfaces and foundation shelves.

\section{Wprowadzenie}

Według patentu [1] sposób posadowienia silników spalinowych na fundamentach (rys. 1) polega na wklejeniu metalowych przekładek w szczeliny między stopami silnika i półkami fundamentu.

Sposób posadowienia silnika spalinowego na fundamencie według wynalazku, w porównaniu do tradycyjnego odlewania podkładek z kompozycji polimerów [2], eliminuje budowę form i układów wlewowych podkładek, co zmniejsza pracochłonność i zużycie kompozycji polimerów, ogranicza pełzanie podkładek, a to zmniejsza relaksację napięcia śrub fundamentowych, daje możliwość stosowania przekładek metalowych o jednakowej grubości na całej długości silnika, a jednocześnie zachowuje główne zalety podkładek metalowych, eliminując ich żmudne dopasowywanie do powierzchni stóp silnika i półek fundamentu.

Na rysunku 2 przedstawiono złącze śrubowe pasowane w kompozycji polimerów, stosowane do posadowienia silników spalinowych i mechanizmów na fundamentach według patentu [3].

Według patentu trzon śruby fundamentowej pokrywa się równomiernie kompozycją polimerów o konsystencji szpachlówki i wprowadza się ruchem śrubowym do otworów łączonych elementów, przy czym w dolnej części złącza na styku trzonu śruby z półką fundamentu umieszcza się uszczelnienie pierścieniowe. Tak wykonane złącze eliminuje kłopotliwą technologicznie obróbkę mechaniczną pasowania trzonu śruby w otworach, zapewnia jednocześnie stabilne i trwałe mocowanie stóp silnika i półek fundamentu.

Zastosowana w wynalazkach kompozycja polimerów musi spełniać wymagania producenta silnika i okrętowego towarzystwa klasyfikacyjnego, do których należą wytrzymałość na ściskanie i wytrzymałość na ścinanie w powierzchniach rozdziału kompozycja polimerów-metal. Autor podjął badania tych charakterystyk dla jednego $\mathrm{z}$ chemoutwardzalnych produktów firmy BELZONA, w war- 
In Figure 2 the invention "Fitted Bolt Joint in Polymer Composite, Applied for Seating Diesel Engines and Mechanisms on Foundations" is presented [3].

According to the invention, the foundation bolt shank is uniformly covered with polymer composite of putty consistence and is introduced with screw motion into the openings of elements joined, sealing rings being located in the lower part of the joint at the contact point of the bolt shank with the foundation shelf.

A joint thus made eliminates the technologically cumbersome mechanical operations of fitting the bolt shank in the openings, at the same time ensuring a stable and durable fixing of the engine feet and foundation shelves.

The polymer composite applied in the inventions has to meet the requirements of engine manufacturer and the ship classification society, among which there are compression and shear strength in the polymer composite-metal separation surface. The author undertook research on the characteristic of a BELZONA chemically hardening product, in layers with thickness characteristic of the inventions presented.

\section{Research results}

The research covered chemically hardened cylindrical casts of polymer composites and steel St $3 \mathrm{~s}$ joints glued with them in accordance with the standard of PN-88/H-84020.

BELZONA $1111 \mathrm{~B}$ product was applied as polymer composite with compression strength $105.5 \mathrm{~N} / \mathrm{mm}^{2}$ according to ASTM D-695, tensile strength $63.4 \mathrm{~N} / \mathrm{mm}^{2}$ according to ASTM D-790, Young module E-1850 N/ $\mathrm{mm}^{2}$ according to ASTM D-695, adhesion to steel $20.7 \mathrm{~N} \cdot \mathrm{mm}^{2}$ according to ASTM D-1000 and hardening shrinkage $\varepsilon_{0}<0.025 \%$ according to DOD-C-324176A [4].

The surfaces of the steel elements of the joints were developed by file treatment $\left(\mathrm{R}_{\mathrm{a}}=1.93-2.74 \mu \mathrm{m}\right)$, degreased with a solvent and covered with polymer composite mixed with a hardener, whereupon the joints were glued with a slight pressure.

For compression strength testing there cylindrical samples were applied of hardened polymer composite of variable height (change of $\mathrm{h}_{\mathrm{o}} / \mathrm{d}_{\mathrm{o}}$ ratio) and glued butt joints, as in Fig. 3 [5]. a)

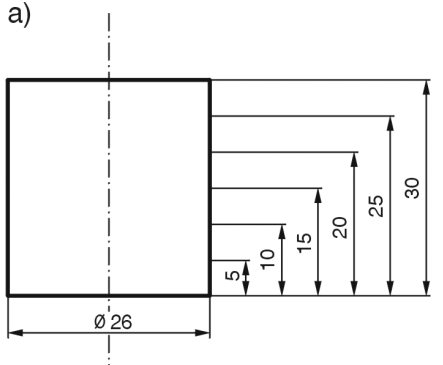

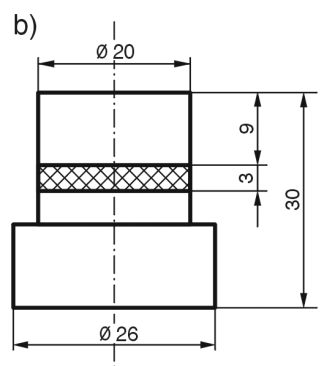

Fig. 3. Samples for compression tests: a) hardened polymer composite casts, b) glued butt joints
Rys.3. Próbki do prób ściskania: a) utwardzonych wyprasek kompozycji polimerów, b) doczołowych złączy klejonych stwach o grubości charakterystycznej dla przedstawionych wynalazków.

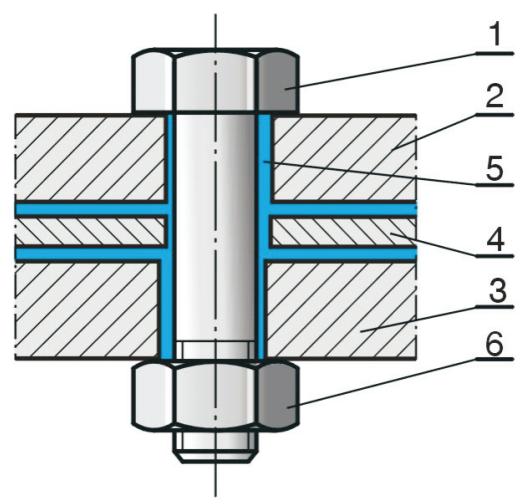

Fig. 2. Bolt joint fitted in polymer composite [3]: 1 - foundation bolt, 2 - engine foot, 3 - foundation shelf, 4 - metal separator, 5 - polymer composite, 6 - nut

Rys. 2. Zlącze śrubowe pasowane w kompozycji polimerów [3]: 1-śruba fundamentowa, 2 - stopa silnika, 3-pótka fundamentu, 4-przekładka metalowa, 5 - kompozycja polimerów, 6-nakrętka

\section{Wyniki badań}

Badaniom poddano chemoutwardzone walcowe wypraski kompozycji polimerów oraz klejone nią złącza stali St3s według PN - 88/H-84020.

Jako kompozycję polimerów zastosowano produkt BELZONA 1111B o wytrzymałości na ściskanie 105,5 $\mathrm{N} / \mathrm{mm}^{2}$ według ASTM D-695, wytrzymałości na rozciąganie $63,4 \mathrm{~N} / \mathrm{mm}^{2}$ według ASTM D-790, module Younga E-1850 $\mathrm{N} / \mathrm{mm}^{2}$ według ASTM D-695, adhezji do stali $20,7 \mathrm{~N} \cdot \mathrm{mm}^{2}$ według ASTM D-1000 i skurczu utwardzania $\varepsilon_{\mathrm{o}}<0,025 \%$ według DOD-C-324176A [4].

Powierzchnie elementów stalowych złączy rozwinięto przez obróbkę pilnikiem $\left(\mathrm{R}_{\mathrm{a}}=1,93-2,74 \mu \mathrm{m}\right)$, odtłuszczono rozpuszczalnikiem i pokryto kompozycją polimerów zmieszaną z utwardzaczem, po czym sklejono złącza z lekkim dociskiem.

Do badań wytrzymałości na ściskanie zastosowano walcowe próbki utwardzonej kompozycji polimerów o zmiennej wysokości (zmiana stosunku $\mathrm{h}_{\mathrm{o}} / \mathrm{d}_{\mathrm{o}}$ ) oraz doczołowe złącza klejone, jak na rys. 3 [5].

Próbki z wyprasek utwardzonej kompozycji polimerów miały zmienną wysokość $h_{0}$ przy stałej średnicy $d_{0}=26$ $\mathrm{mm}$. Próbki doczołowego złącza klejonego miały warstwy kompozycji polimerowej o grubości 1, 2, 3, 4 i 5 mm.

Próby ściskania przeprowadzono na maszynie wytrzymałościowej MTS zgodnie z PN-ISO 4385. Przy ściskaniu próbek następowało wybrzuszenie warstwy kompozycji polimerów. W zakresie stosowanych obciążeń (do uzyskania $\sigma_{\mathrm{d} 2}$ ) pęknięć na wybrzuszeniach kompozycji polimerów próbek nie stwierdzono.

W próbach wyznaczano umowną granicę plastyczności $\sigma_{\mathrm{d} 0,2}$ i granicę wytrzymałości na ściskanie $\sigma_{\mathrm{d} 2}$ według PN ISO 4385. Wyniki badań wytrzymałości próbek na ściskanie przedstawiono na rys. 4-6. 
Samples of hardened polymer composite casts were of variable height $h_{o}$ with constant diameter $d_{o}=26 \mathrm{~mm}$. Samples of glued butt joint had polymer composite layers of 1 , 2, 3, 4 and $5 \mathrm{~mm}$ thickness.

Compression tests were carried out on MTS testing machine in accordance with the standard of PN-ISO4385. When the samples were compressed, the polymer composite layer bulged. In the range of loads applied (for obtaining $\sigma_{\mathrm{d} 2}$ ) no cracks were found on the bulges of polymer composite samples.

A conventional plasticity limit of $\sigma_{\mathrm{d} 0,2}$ and a compression strength limit of $\sigma_{\mathrm{d} 2}$ were determined in the tests in accordance with PN-ISO 4385 standard. Results of the compression strength tests of the samples have been presented in Fig. 4-6.

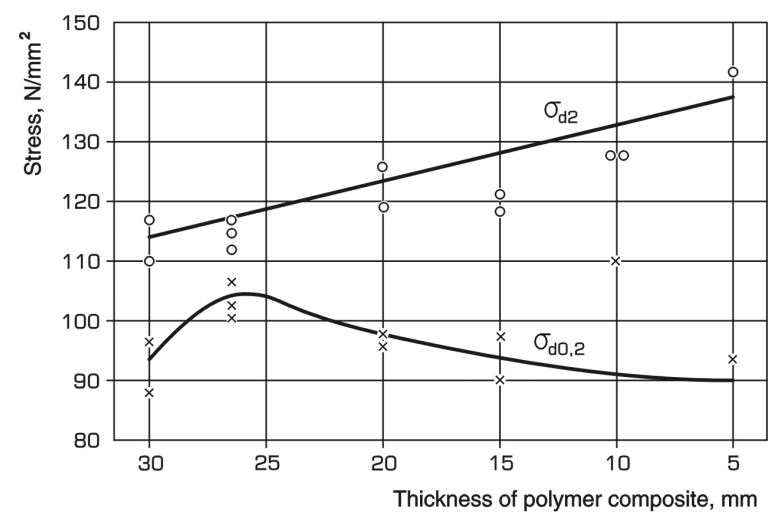

Fig. 4. Dependence of compression strength $\sigma_{\mathrm{d} 0,2}$ and $\sigma_{\mathrm{d} 2}$ on height ho of cylindrical $\left(\mathrm{d}_{\mathrm{o}}=26 \mathrm{~mm}\right)$ Belzon $1111 \mathrm{~B}$ polymer composite casts

Rys. 4. Zależność wytrzymałości na ściskanie $\sigma_{d 0.2} i \sigma_{d 2}$ od wysokości $h_{o}$ walcowych $\left(d_{o}=26 \mathrm{~mm}\right)$ wyprasek kompozycji polimerów Belzona $1111 \mathrm{~B}$

As can be seen (Fig. 4), Belzona 1111B polymer composite on standard samples $\left(\mathrm{h}_{\mathrm{o}}=\mathrm{d}_{\mathrm{o}}\right)$ showed $\sigma_{\mathrm{d} 2 \min }=111 \mathrm{~N} / \mathrm{mm}_{2}$, that is higher than the one guaranteed by the manufacturer, $\sigma_{\mathrm{d} 2}=105.5 \mathrm{~N} / \mathrm{mm}^{2}$ [4].

As can be seen from Fig. 5 with decreased $h_{o} / d_{o}$ ratio of the samples the compression strength of Belzona 1111B polymer composites increases, which bids well for applying the composites in washers according to the patent, with ratio $\mathrm{h}_{\mathrm{o}} / \mathrm{d}_{\mathrm{o}}<0.2$.

According to the patent it is anticipated in the washers to apply polymer composite layers of 3-5 mm thickness. As can be seen in Fig. 6, when applying Belzona 1111B polymer composites in the washers, it can be expected to obtain compression strength of the washers of $\sigma_{\mathrm{d} 2 \min }=200$ $\mathrm{N} / \mathrm{mm}^{2}$, which fulfils the requirements [6].

For testing shear strength of the washers in the polymer composite-metal separation surfaces, samples were applied of an overlap glued joint of shape and dimensions as in Fig. $7[5]$.

Variable thickness of polymer layer: 1, 2, 3 and $5 \mathrm{~mm}$ was applied in the samples.

The shape and dimensions of the samples were proportional to real cast polymer washers applied for seating diesel
Jak pokazuje rys. 4, kompozycja polimerów Belzona $1111 \mathrm{~B}$ na standardowych próbkach $\left(\mathrm{h}_{\mathrm{o}}=\mathrm{d}_{\mathrm{o}}\right)$ wykazała $\sigma_{\mathrm{d} 2 \min }$ $=111 \mathrm{~N} / \mathrm{mm}^{2}$, a więc większą niż gwarantowana przez producenta $\sigma_{\mathrm{d} 2}=105,5 \mathrm{~N} / \mathrm{mm}^{2}$ [4].

Rysunek 5 pokazuje, że ze zmniejszeniem stosunku $\mathrm{h}_{\mathrm{o}} / \mathrm{d}_{\mathrm{o}}$ próbek wytrzymałość na ściskanie kompozycji polimerów Belzona 1111B zwiększa się. Są to dobre rokowania odnośnie do stosowania kompozycji w podkładkach według patentu, w których stosunek $\mathrm{h}_{\mathrm{o}} / \mathrm{d}_{\mathrm{o}}<0,2$.

W podkładkach według patentu przewiduje się stosowanie warstw kompozycji polimerów o grubości 3-5 mm. Jak widać na rys. 6, przy zastosowaniu w podkładkach kompozycji polimerów Belzona 1111B można liczyć na uzyskanie wytrzymałości podkładek na ściskanie $\sigma_{\mathrm{d} 2 \min }=200 \mathrm{~N} / \mathrm{mm}^{2}$, co stanowi spełnienie wymagań przepisów [6].

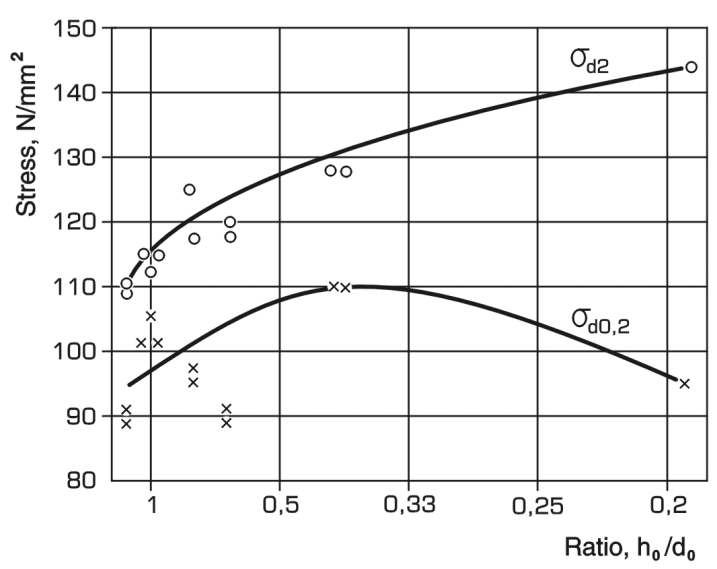

Fig. 5. Dependence of compression strength $\sigma_{\mathrm{d} 2}$ of Belzon 1111B polymer composite casts on $\mathrm{h}_{\mathrm{o}} / \mathrm{d}_{\mathrm{o}}$ ratio of the samples

Rys. 5. Zależność wytrzymałości na ściskanie $\sigma_{d 2}$ wyprasek kompozycji polimerów Belzona $1111 \mathrm{~B}$ od stosunku $h_{o} / d_{o}$ próbek

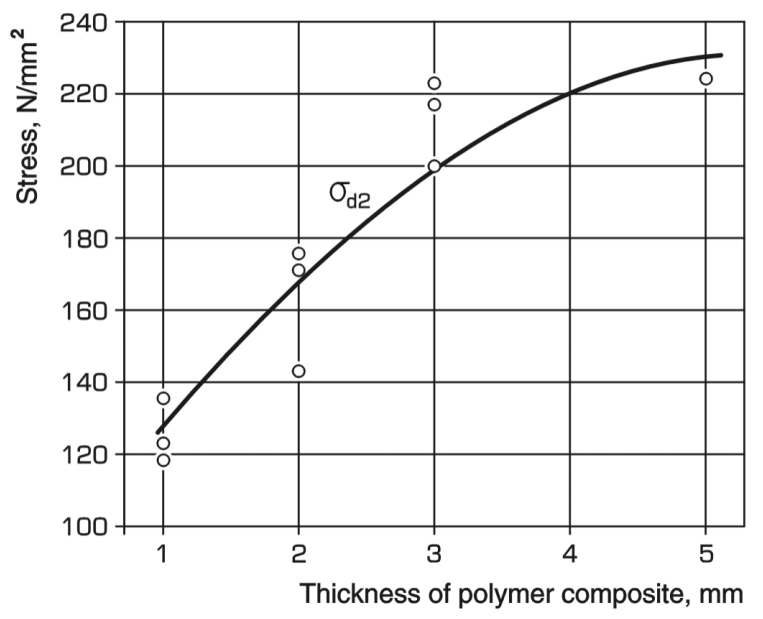

Fig. 6. Dependence of compression strength $\sigma_{\mathrm{d} 2}$ on the thickness of Belzon 1111B polymer composite layer in samples of glued butt joints

Rys. 6. Zależność wytrzymałości na ściskanie $\sigma_{d 2}$ od grubości warstwy kompozycji polimerów Belzona 1111 B w próbkach doczołowych złączy klejonych 
engines on foundations in marine power plants. In accordance with the regulations of Germanischer Lloyd [6] the glued joint samples were tightened with two bolts simulating real foundation bolts. They were tightened with forces of 700,4200 and $7700 \mathrm{~N}$, which conventionally correspond to one, six and eleven weights of a seated engine.

As can be seen in Fig. 7, the diameter of bolt shanks connecting the joint was smaller than the bolt opening diameter so that the bolts should not impair shearing the joint in planes of polymer composite-metal separation in the tensile test.

The results of shear strength tests of overlap glued joint samples have been presented in Fig. 8.

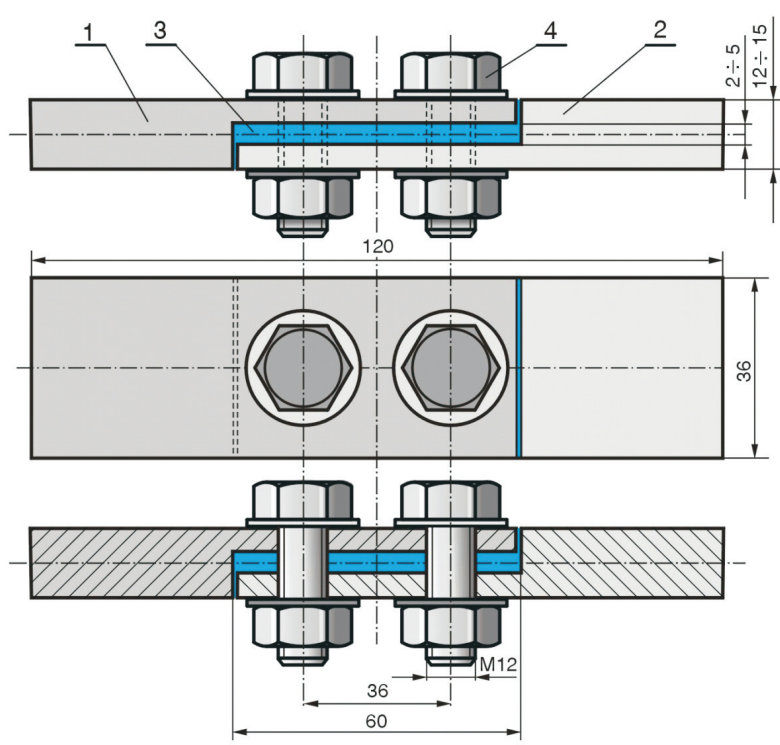

Fig. 7. Sample of overlap joint glued with polymer composite: 1, $2-$ steel parts of the joint, 3 - polymer composites, 4 - bolt connectors

Rys. 7. Próbka zakładkowego złącza klejonego kompozycja polimerów: 1,2 - częśsi stalowe złącza, 3-kompozycja polimerów, 4-łączniki śrubowe

In Figure 8 the points related to joints with $5 \mathrm{~mm}$ thickness of polymer composite layer are the mean shear strength values of 5 sample joints. The remaining points are shear strength values of particular test joints.

Tensile tests of the joints were carried out on MTS testing machine. Destruction of the joints took place by shearing in the polymer composite-metal separation surfaces, the shearing starting on both ends of the overlap. In a small degree the loss of joint cohesion was caused by breaking the polymer composite layer.

Due to technological considerations, according to the patent polymer composite layers of $3 \mathrm{~mm}$ thickness or more can be applied in the washers. As can be seen in Fig. 8 with such thickness of polymer composite layers, with increased tension of connecting bolts above $4200 \mathrm{~N}$ the shear strength of the joints increases more slowly. With the thickness of polymer composite layers of $5 \mathrm{~mm}$ the increase of shear strength of the joints along with the increase of connecting bolts tension is insignificant. Hence, it can be concluded that according to the patent in the washers with the thickness of polymer composite
Do badań wytrzymałości podkładek na ścinanie w powierzchniach rozdziału kompozycja polimerów-metal zastosowano próbki zakładkowego złącza klejonego o kształcie i wymiarach, jak na rys. 7 [5].

W próbkach stosowano zmienną grubość warstwy polimerów: 1, 2, 3 i 5 mm.

Kształt i wymiary próbek były proporcjonalne do rzeczywistych odlewanych podkładek polimerowych, stosowanych do posadowienia silników spalinowych na fundamentach w siłowniach okrętów. Zgodnie z wymaganiami przepisów Germanischer Lloyd [6] próbki złącza klejonego były ściągane dwoma śrubami, symulującymi rzeczywiste śruby fundamentowe. Śruby napinano siłami 700, 4200 i 7700 N, które umownie odpowiadają jednemu, sześciu i jedenastu ciężarom posadowionego silnika.

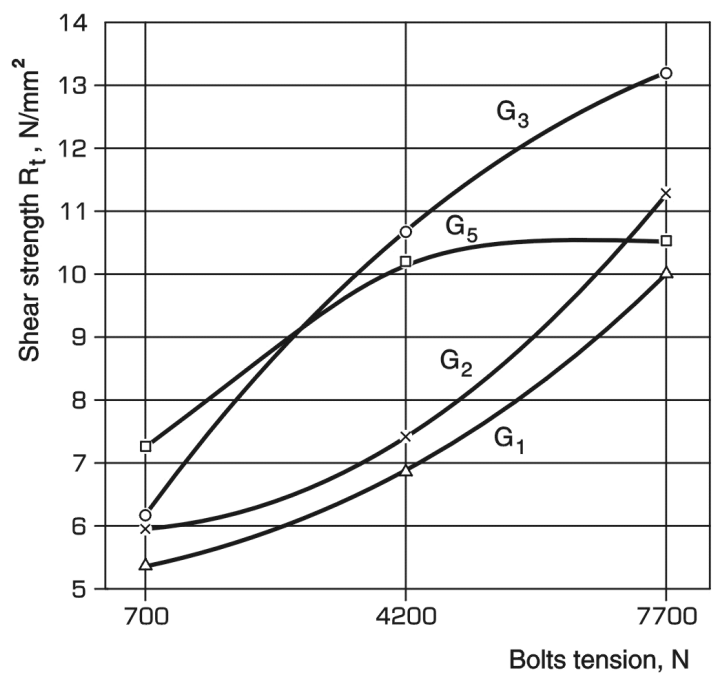

Fig. 8. Change of shear strength of sample overlap glued joints depending on the tension of connecting bolts and the thickness of polymer composite layer: $\mathrm{G}_{1}-1 \mathrm{~mm}, \mathrm{G}_{2}-2 \mathrm{~mm}, \mathrm{G}_{3}-3 \mathrm{~mm}, \mathrm{G}_{5}-5 \mathrm{~mm}$

Rys. 8. Zmiana wytrzymałości na ścinanie próbnych zakładkowych złączy klejonych zależnie od napięcia śrub tączacych i grubości warstwy kompozycji polimerów: $G_{1}-1 \mathrm{~mm}, G_{2}-2 \mathrm{~mm}, G_{3}-3 \mathrm{~mm}, G_{5}-5 \mathrm{~mm}$

Jak pokazuje rys. 7 , średnica trzonów śrub łączących złącze była mniejsza od średnicy otworów na śruby, tak aby śruby nie utrudniały ścięcia złącza w płaszczyznach rozdziału kompozycja polimerów-metal w próbie rozciągania.

Wyniki badań wytrzymałości na ścinanie próbek zakładkowego złącza klejonego przedstawiono na rys. 8 .

Na rysunku 8 punkty dotyczące złączy o $5 \mathrm{~mm}$ grubości warstwy kompozycji polimerów są średnimi wartościami wytrzymałości na ścinanie 5 złączy próbnych. Pozostałe punkty są wartościami wytrzymałości na ścinanie pojedynczych złączy próbnych.

Próby rozciągania złączy przeprowadzono na maszynie wytrzymałościowej MTS. Zniszczenie złączy następowało przez ścięcie w powierzchniach rozdziału kompozycja polimerów-metal, przy czym ścięcie zaczynało się od obu końców zakładki. W niewielkim procencie utrata spójności złącza była spowodowana rozerwaniem warstwy kompozycji polimerów. 
layers of $5 \mathrm{~mm}$, the tension of foundation bolts can be limited to the force equal to six weights of the seated diesel engine without an essential loss of the washers shear strength in the polymer composite-steel separation surfaces.

The designated joint shear strengths in polymer compositemetal separation surfaces are derivatives of the static friction coefficient of polymer against steel, assumed as equal to 0.7 [7]. With steel washers, the force necessary to shift a washer on the foundation is a derivative of static friction coefficient of steel against steel, which is equal to 0.1 . Hence, it may be assumed that shifting on the foundation of a diesel engine seated on washers according to the patent will require a considerably larger force than the shifting on the foundation of an engine seated on steel washers. In the seating construction of the engine on the foundation in the marine plant, this permits the reduction of the number of side and head stoppers and fitted foundation bolts, traditionally applied for safeguarding the engine against displacement against the foundation.

Research on the effect of polymer composite layer thickness on the shear strength of joints in the polymer compositemetal separation surfaces must be considered as a piloting one, due to the small number of trial joints tested. It seems necessary to continue this research.

\section{Conclusions}

The results of research on steel joints with Belzona 1111B polymer composites allow predictions as to the washers according to the patent:

1. The compression strength of the washers may be larger than the compression strength of the polymer composite applied.

2. With the tension of foundation bolts equal to six weights of the diesel engine seated on washers according to the patent, better safeguarding against the engine displacement against the foundation can be obtained than when applying metal washers.

\section{Bibliography/Literatura}

[1] Urząd Patentowy RP. Patent nr 192120. Sposób posadawiania silników i mechanizmów na podstawach fundamentowych. Uprawniona z patentu Akademia Marynarki Wojennej w Gdyni. Twórca wynalazku Leszek Piaseczny. 2.10.2006.

[2] Grudziński K., Jaroszewicz W.: Posadawianie maszyn i urządzeń na podkładkach fundamentowych odlewanych z tworzywa EPY. ZAPOL. Szczecin 2002.

[3] Urząd Patentowy RP. Patent nr 195515. Złącze śrubowe pasowane $\mathrm{w}$ kompozycji polimerów. Uprawniona $\mathrm{z}$ patentu Akademia Marynarki Wojennej w Gdyni. Twórca wynalazku Leszek Piaseczny. 28.09.2007.

[4] Masek R.: Co to jest kompozyt? Materiały konferencji naukowo-technicznej „Belzona na pokładzie”. Łeba 8.03.2007 r., s. 3-14. Belse. Bielsko-Biała 2007.

[5] Piaseczny L.: Posadawianie silników w siłowniach okrętów na podkładkach polimerowo-metalowych. Combustion Engines, nr 4, 2008.

[6] Germanischer Lloyd. Regulation for seating propulsion plants. Hamburg. April 1995.

[7] Wilson J.M.: Marine epoxy resin chocks. vol.21, Nr 1, pp.1218. 1984.
Ze względów technologicznych w podkładkach według patentu mogą być stosowane warstwy kompozycji polimerów o grubości $3 \mathrm{~mm}$ i większej. Jak widać na rys. 8, przy tych grubościach warstw kompozycji polimerów, ze zwiększeniem napięcia śrub łączących powyżej $4200 \mathrm{~N}$ wytrzymałość złączy na ścinanie zwiększa się wolniej. Przy grubości warstw kompozycji polimerów $5 \mathrm{~mm}$ zwiększenie wytrzymałości złączy na ścinanie ze zwiększeniem napięcia śrub łączących jest nieznaczne. Stąd można wyciągnąć wniosek, że w podkładkach według patentu o grubościach warstw kompozycji polimerów 5 mm można ograniczyć napięcie śrub fundamentowych do siły równej sześciu ciężarom posadowionego silnika spalinowego, bez istotnego ubytku wytrzymałości podkładek na ścinanie w powierzchniach rozdziału kompozycja polimerów-stal.

Wyznaczone wytrzymałości złączy na ścinanie w powierzchniach rozdziału kompozycja polimerów-metal są pochodnymi współczynnika tarcia spoczynkowego polimeru o stal, który przyjmuje się jako równy 0,7 [7]. Przy podkładkach stalowych siła potrzebna do przesunięcia podkładki na fundamencie jest pochodną współczynnika tarcia spoczynkowego stali o stal, który jest równy 0,1 . Stąd można przyjąć, że przesunięcie na fundamencie silnika spalinowego osadzonego na podkładkach według patentu będzie wymagało działania znacznie większej siły niż przesunięcie na fundamencie silnika osadzonego na podkładkach stalowych. Pozwala to w konstrukcji posadowienia silnika na fundamencie w siłowni okrętu zmniejszyć liczbę stoperów bocznych i czołowych oraz pasowanych śrub fundamentowych, tradycyjnie stosowanych do zabezpieczenia silnika przed przesunięciem na fundamencie.

Badania wpływu grubości warstwy kompozycji polimerów na wytrzymałość złączy na ścinanie w powierzchniach rozdziału kompozycja polimerów-metal należy uznać za pilotowe, ze względu na małą liczbę zbadanych złączy próbnych. Wydaje się, że jest potrzebne kontynuowanie tych badań.

\section{Wnioski}

Uzyskane wyniki badań złączy stali z kompozycją polimerów Belzona 1111B pozwalają prognozować odnośnie do podkładek według patentu, że:

1. Wytrzymałość podkładek na ściskanie może być większa od wytrzymałości na ściskanie zastosowanej kompozycji polimerów.

2.Przy napięciu śrub fundamentowych równym sześciu ciężarom silnika spalinowego osadzanego na podkładkach według patentu można uzyskać większe zabezpieczenie przed przesunięciem silnika na fundamencie niż uzyskuje się przy zastosowaniu podkładek metalowych.

Paper reviewed

Prof. Leszek Piaseczny, DSc, DEng. - Professor in the Mechanical-Electric Faculty at Naval University of Gdynia.

Prof. dr hab. inż. Leszek Piaseczny - profesor na Wydziale Mechaniczno-Elektrycznym Akademii Marynarki Wojennej w Gdyni.

e-mail: piaseczny@ptnss.pl 